\title{
Bauhinia darainensis Thulin \& Nusb. (Fabaceae), a new species from northern Madagascar
}

\author{
Mats Thulin, Louis Nusbaumer \& Laurent Gautier
}

\begin{abstract}
THULIN, M., L. NUSBAUMER \& L. GAUTIER (2014). Bauhinia darainensis Thulin \& Nusb. (Fabaceae), a new species from northern Madagascar. Candollea 69: 135-139. In English, English and French abstracts.

Bauhinia darainensis Thulin \& Nusb. (Fabaceae), a new species from the Loky-Manambato region of north-eastern Madagascar, is described and illustrated. The species is believed to be most closely related to Bauhinia decandra Du Puy \& R. Rabev. from south-central and southern Madagascar and Bauhinia hildebrandtii Vatke that is widespread in northern Madagascar. Bauhinia darainensis differs from both these species notably by its white petals, with the upper petal pink towards the tip, and by its stamen arrangement with three longer and seven shorter and more slender stamens. The distribution and ecology of the new species are discussed and a preliminary IUCN Red List conservation assessment is proposed.
\end{abstract}

\section{Key-words}

FABACEAE - Bauhinia - Madagascar - Daraina -

Taxonomy - Conservation

\begin{abstract}
Résumé
THULIN, M., L. NUSBAUMER \& L. GAUTIER (2014). Bauhinia darainensis Thulin \& Nusb. (Fabaceae), une nouvelle espèce du nord de Madagascar. Candollea 69: 135-139. En anglais, résumés anglais et français.

Bauhinia darainensis Thulin \& Nusb. (Fabaceae), une nouvelle espèce de la région de Loky-Manambato au nord-est de Madagascar, est décrite et illustrée. Cette espèce est vraisemblablement proche de Bauhinia decandra Du Puy \& R. Rabev. du centre-sud et du sud de Madagascar et de Bauhinia hildebrandtii Vatke qui est largement distribuée dans le nord de Madagascar. Bauhinia darainensis diffère particulièrement de ces deux espèces par ses pétales blancs avec le pétale supérieur rose vers l'apex, et par l'organisation de ses étamines: trois longues et sept plus courtes et plus graciles. La distribution et l'écologie de cette nouvelle espèce sont discutées et un statut préliminaire de conservation selon la Liste Rouge de l'UICN est proposé.
\end{abstract}

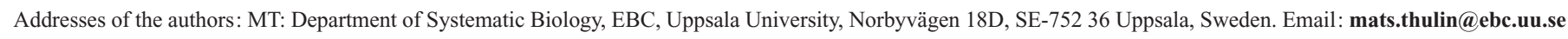

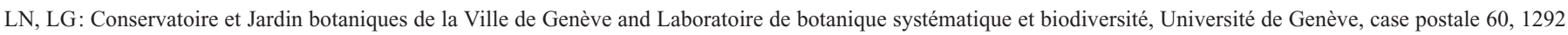
Chambésy, Switzerland. 


\section{Introduction}

Du Puy \& RabeVohitra (2002) recognized 16 species of Bauhinia L. (Fabaceae) native to Madagascar, of which 15 are endemic to the island. During the naming of Malagasy collections of legumes sent for identification from MO to one of us (MT), a collection of Bauhinia was encountered that could not be matched with any previously known species. As this collection originated from a forest patch of the Daraina region in northeastern Madagascar, an enquiry was made to the Conservatoire et Jardin botaniques de la Ville de Genève, an institution that had for several years been involved in botanical inventories of this region (GAUTIER \& al., 2006; NUSBAUMER $\&$ al., 2010). A second collection of the new species from the same forest patch was then located.

The recent botanical exploration of Daraina has shown this region to be an important area of local endemism. The area is now protected as a Multiple Usage Forest Station (MUFS) referred to as Loky-Manambato (WAHLERT \& al., 2013). The new species of Bauhinia described here brings further weight to the importance of Loky-Manambato as a conservation area.

\section{Taxonomic treatment}

Bauhinia darainensis Thulin \& Nusb., spec. nova (Fig. 1-2).

Typus: Madagascar. Prov. Antsiranana: SAVA Region, Vohemar, Daraina, village Befarafara, forêt de Solanampilana au N de Daraina, $13^{\circ} 05^{\prime} 42^{\prime}$ 'S 49³4'57' E, $137 \mathrm{~m}$, 9.XII.2006, fl., Randrianaivo \& al. 1430 (holo-: UPS!; iso-: CNARP, MO-6310175!, P [P00754864]!, TAN).

Bauhinia darainensis Thulin \& Nusb. is similar to B. decandra Du Puy \& R. Rabev. and B. hildebrandtii Vatke in having 10 fertile stamens, but differs from both of them by having shorter racemes with only 2-3 (not up to 10 or more) flowers, flowers with a 4-6.5 mm (not 10-25 mm) long hypanthium, white (not orange-red) petal blades with the blade of the upper petal pink towards the tip (not with a yellow blotch), petal claws glabrous or with a few scattered hairs (not distinctly pubescent), and by having 3 longer and 7 shorter and more slender stamens (not 5 longer and 5 shorter stamens).

Shrub, c. $1.5 \mathrm{~m}$, or tree up to $11 \mathrm{~m}$ tall, flowering along with mature foliage; twigs slender, purplish brown, densely pubescent with short spreading hairs when young, with whitish lenticels. Leaves simple, bilobed, with an acicular pubescent mucro 2-5 mm long in the sinus; stipules linear, 5-7 mm long, acuminate, pubescent, caducous; petiole 8-40 mm long, densely pubescent with spreading hairs; lamina membranous, broadly ovate, divided from about midway to $2 / 3$ of the length, 1.5-8.2 $\times 1.8-8.8 \mathrm{~cm}$, shallowly to deeply cordate at the base, the lobes obtuse to subacute, glabrous above, pubescent beneath, with 9 main veins from the base. Racemes 2-3-flowered, the flowers opening sequentially; axis 10-17 mm long, densely pubescent with spreading hairs; bracts linear-lanceolate, 4-5.5 mm long, pubescent; pedicels $8-11 \mathrm{~mm}$ long, densely pubescent; bracteoles filiform, 1.5-3.5 mm long, pubescent. Flowers c. $4 \mathrm{~cm}$ across; hypanthium narrowly funnel-shaped, 4-6.5 mm long, pubescent. Calyx spathe-like, 1.8-2.5 cm long, pubescent, with 5 linear teeth 1-3 mm long at the apex, not winged. Petals white with greenish claws, the upper petal suffused with pink towards the tip but white along main nerve and lower parts of secondary nerves, subequal, suberect to somewhat spreading, straight or with the blades slightly curved backwards to reflexed, glabrous or with a few scattered hairs, 3.0-4.0 cm long, the 4 lateral petals with the blade broadly elliptic $2.0-2.5 \times 1.1$ $1.2 \mathrm{~cm}$, subacute at the apex, attenuate at the base, upper petal with the blade ovate, $2.0-2.5 \times 1.2-1.3 \mathrm{~cm}$, obtuse at the apex, gradually tapering at the base and with a narrow wing along the margin of the claw almost to the base. Stamens 10, all fertile, glabrous except for pubescence of long white hairs at the base of the filaments; 3 longer, 15-20 mm long, with anthers 2.5$3 \mathrm{~mm}$ long, the 7 others $7-14 \mathrm{~mm}$ long, more slender, with anthers c. $2 \mathrm{~mm}$ long. Ovary c. $10 \mathrm{~mm}$ long, shortly stipitate, pubescent at base and sometimes along upper margin with long white hairs, on the sides with short brownish \pm appressed tubercle-based hairs, with c. 15 ovules; style 16-18 mm long, glabrous or with scattered white hairs; stigma enlarged and oblique, c. $1.5 \mathrm{~mm}$ across, papillate. Young pods with a pubescent stipe c. $5 \mathrm{~mm}$ long, linear-oblong, 50-60 × 7-8 mm, apiculate, subglabrous with scattered white hairs and brownish tubercle-based hairs particularly towards the base.

Notes. - Bauhinia darainensis appears to be most closely related to $B$. decandra Du Puy \& R. Rabev. and $B$. hildebrandtii Vatke, two other species with 10 fertile stamens of varying length. Bauhinia decandra is restricted to south-central and southern Madagascar, whereas $B$. hildebrandtii is fairly widespread in northern Madagascar, including Daraina, and also has been recorded from the Comoro Islands (DU PUY \& RABEVOHITRA, 2002). Bauhinia darainensis differs from both $B$. decandra and $B$. hildebrandtii by its shorter racemes (axis 10-17 $\mathrm{mm}$ versus up to $90 \mathrm{~mm}$ long) with only 2-3 (not up to 10 or more) flowers, hypanthium 4-6.5 mm (not 10-25 mm) long, petal blades white, the one at the uppermost position pink towards the tip (versus petal blades orange red, the one of the upper petal with a yellow blotch), petal claws glabrous or almost so (not distinctly pubescent), and by its three longer and seven shorter, more slender stamens (not five longer and five shorter stamens).

From the sympatric and subglabrous $B$. hildebrandtii, $B$. darainensis can also be separated by being pubescent in most parts. Due to its dense indumentum of spreading hairs on young stems and leaf undersides, it can be easily distinguished also in a sterile state. 


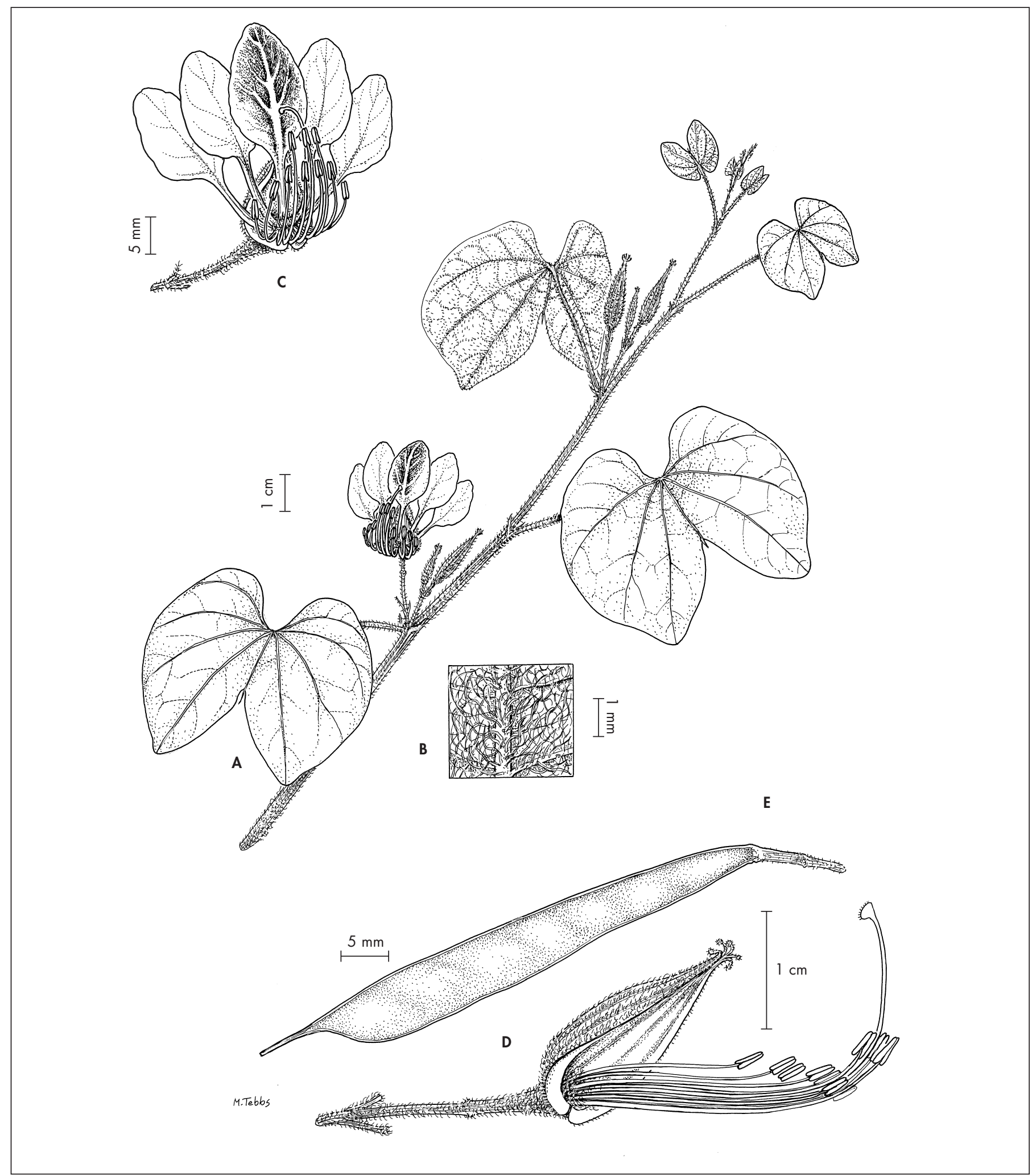

Fig. 1. - Bauhinia darainensis Thulin \& Nusb. A. Flowering branch; B. Underside of leaf showing indumentum; C. Flower, front view; D. Flower with petals removed, side view; E. Young pod.

[A-C: Randrianaivo \& al. 1430, UPS; D: Nusbaumer \& Ranirison 2031, G] [Drawn by M. Tebbs] 

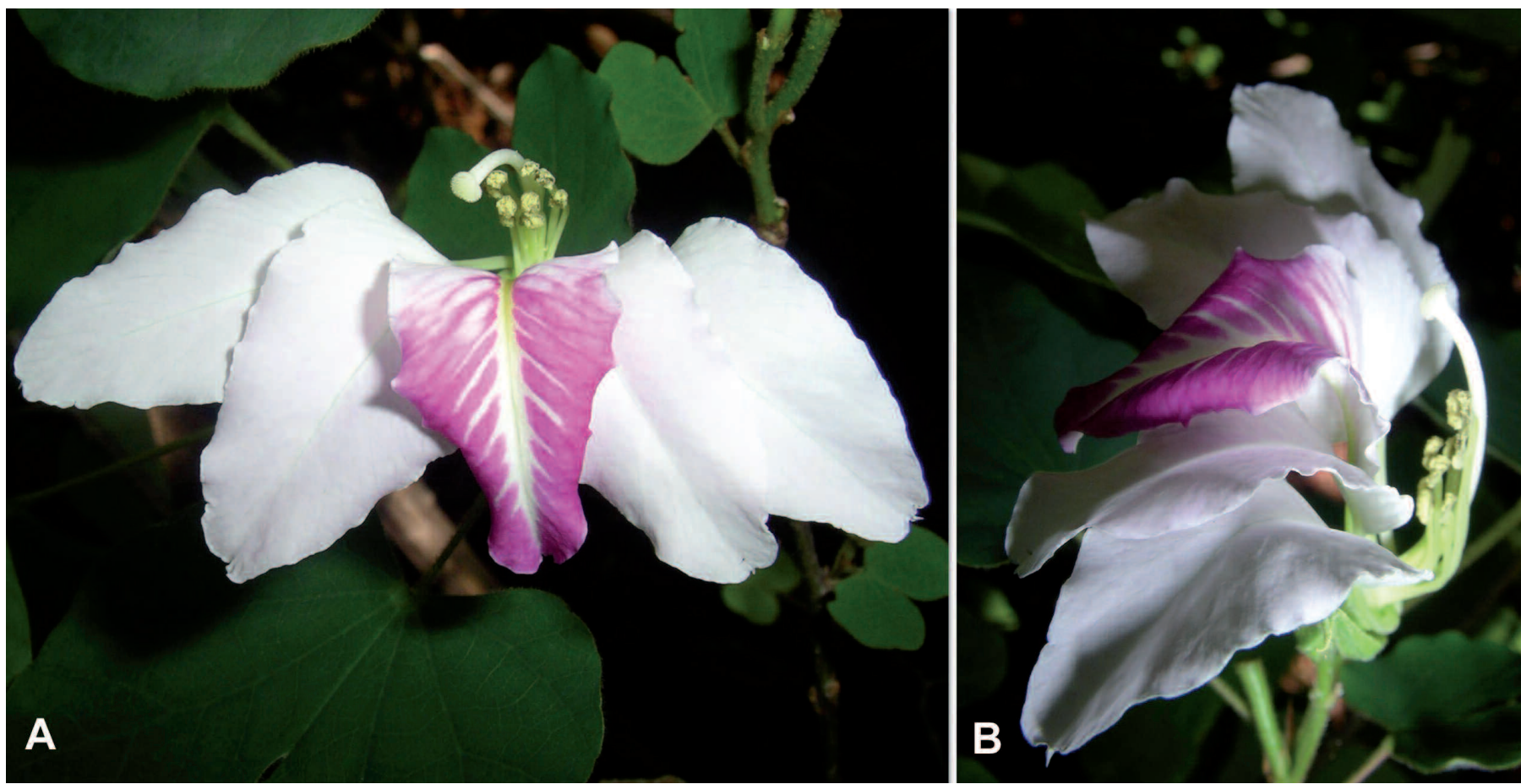

Fig. 2. - Flower of Bauhinia darainensis Thulin \& Nusb. A. Top view, showing the reflexed petal blades of the flower; B. Side view.

[Nusbaumer \& Ranirison 2031, G] [Photo: L. Nusbaumer]

Distribution and ecology. - The new species is known only from the Solaniampilana-Maroadabo, Bekaraoka, Ampondrabe and Ankaramy forests in the Loky-Manambato region (Daraina) in northeastern Madagascar. A total of about 60 individuals were observed among all these localities during a vegetation study, which included more than 54,000 records of plant occurrences in the ten main forest areas of the region (NUSBAUMER, 2011).

Bauhinia darainensis was observed at elevations between 100 and $450 \mathrm{~m}$ above sea level, mainly in primary dry $(60 \%$ of the occurrences), but also in mesophilous, ripicolous and sclerophyllous forest. The canopies of the forests where it occurs reach up to $12 \mathrm{~m}$ with emergent trees up to $16 \mathrm{~m}$ tall. The species most frequently recorded together with $B$. darainensis are, in decreasing order: Grossera perrieri Leandri (Euphorbiaceae), Dracaena xiphophylla Baker (Asparagaceae), Ehretia cymosa Thonn. (Boraginaceae), Strychnos madagascariensis Poir. (Loganiaceae), Ambilobea madagascariensis (Capuron) Thulin \& al. (Burseraceae), Mallotus oppositifolius (Geiseler) Müll. Arg. (Euphorbiaceae), Drypetes perrieri Leandri (Putranjivaceae), Strychnos decussata (Pappe) Gilg (Loganiaceae), Hildegardia ankaranensis (Arènes)
Kosterm. (Malvaceae), Wielandia fadenii (Radcl.-Sm.) Petra Hoffm. \& McPherson (Phyllanthaceae), Commiphora ankaranensis (J. F. Leroy) Cheek \& Rakot. (Burseraceae), Delonix boiviniana (Baill.) Capuron (Fabaceae), Grevea madagascariensis Baill. (Montiniaceae) and Coptosperma sp. (Rubiaceae).

Phenology. - Collections in flower, and in flower and young fruit, have been made in December and February, respectively.

Conservation status. - With an "Area of Occupancy" (AOO) of $54 \mathrm{~km}^{2}$ and an "Extent of Occurrence" (EOO) of $362 \mathrm{~km}^{2}$, two herbarium collections and 60 further observations among five subpopulations, of which three in the temporarily protected Loky-Manambato area, Bauhinia darainensis is assigned a preliminary status of "Vulnerable" (VU D2) following the IUCN Red List Categories and Criteria (IUCN, 2012).

Paratypi. - Madagascar. Prov. Antsiranana: sous-préfecture de Vohemar, commune rurale de Daraina, forêt de SolaniampilanaMaroadabo, 1305'44'"S 49³4'26'E, 248 m, 7.II.2006, fl. \& imm. fr., Nusbaumer \& Ranirison 2031 (G [G00090379]!, MO-5997545!, $\mathrm{P}$ [P00466005]!, TEF!). 


\section{Acknowledgements}

We are indebted to the curators of the herbaria $\mathrm{G}, \mathrm{K}, \mathrm{MO}$, P, UPS and TEF for access to their collections, to Patrick Ranirison and Richard Randrianaivo for herbarium specimens, to Margaret Tebbs for the drawing, and to Gwilym Lewis and Martin Callmander for helpful comments on the manuscript. LN and LG thank Prof. Rodolphe Spichiger and Dr PierreAndré Loizeau for supporting the research in Loky-Manambato. Our research was funded by CJBG, Université de Genève, Conservation International (CBC fund), Malagasy NGO Fanamby, Fondation Jean-Marcel Aubert, and Vontobel Stiftung. We also thank the Direction Générale des Eaux et Forêts de Madagascar and the Département de Biologie et Ecologie Végétale de l'Université d'Antananarivo for supporting our project in Loky-Manambato.

\section{References}

Du Puy, D. J. \& R. Rabevohitra (2002). Tribe Cercideae. In: Du Puy, D. J., J.-N. LABAt, R. RABEVOhitra, J.-F. Villiers, J. Bosser \& J. MoAT (ed.), The Leguminosae of Madagascar: 104-127. Royal Botanic Gardens, Kew.

GAUtier, L., P. RANirison, L. NUSBaumer \& S. WOHLhaUSER (2006). Aperçu des massifs forestiers de la region Loky-Manambato. In: Goodman, S. M. \& L. WiLmÉ (ed.), Inventaires de la faune et de la flore du Nord de Madagascar dans la région Loky-Manambato, Analamerana et Andavakoera: 81-99. CIDST, Ministère de l'Education Nationale et de la recherche Scientifique, Antananarivo.

IUCN (2012). IUCN Red List Categories and Criteria: version 3.1. $2^{\text {nd }}$ edition. IUCN Species Survival Commission, Gland \& Cambridge.

NusBaumer, L. (2011). Species distribution patterns in steep environmental gradients: downscaling of a biogeographical framework (Loky-Manambato Region, NE Madagascar). PhD. thesis, University of Geneva.

Nusbaumer, L., P. Ranirison, L. Gautier, C. Chatelain, P.-A. LoizeAu \& R. SPichiger (2010). Loky-Manambato: point de rencontre des principales unités phytogéographiques de Madagascar. In: Van Der Burgt, X., J. Van Der Maesen \& J.-M. Onana (ed.), Systématique et conservation des plantes africaines: 253264. Royal Botanic Gardens, Kew.

Wahlert, G. A., P. B. Phillipson, L. Nusbaumer \& L. Gautier (2013). Cyphostemma darainense Wahlert \& Phillipson (Vitaceae), a new species from northeastern Madagascar. Candollea 67: 277283. 